\title{
The Critical Causes and Effects of Cost Overruns in Public Sector Construction Projects in Port Harcourt, Nigeria
}

\author{
Olupitan, A.L ${ }^{1}$, Ajator U.O. ${ }^{2}$ and Nzeneri, O.P . ${ }^{3}$ \\ ${ }^{1}$ A.L Oluptan \& Partners Ltd, Port Harcourt, Rivers State, Nigeria. \\ ${ }^{2}$ Department of Quantity Surveying, Nnamdi Azikiwe University, Awka, Nigeria \\ ${ }^{3}$ Department of Building, Federal University of Technology, Owerri, Nigeria \\ DOI: 10.29322/IJSRP.11.10.2021.p11835 \\ http://dx.doi.org/10.29322/IJSRP.11.10.2021.p11835
}

\begin{abstract}
This study was conducted to identify the critical causes and impacts of cost overruns on public sector construction projects in Port Harcourt metropolis. It further attempts to determine the measures that can be taken to minimize the impacts of cost overruns on public sector construction projects and to establish critical success factors for public sector construction projects in Port Harcourt metropolis. Structured questionnaires were used to determine the participants' responses with respect to the identified factors from the reviewed literature. These respondents were mainly registered construction professionals working in Port Harcourt. The data generated were analyzed using mean item score and ranked accordingly. Findings from the survey revealed that the causes of the most severe cost overruns were variation orders, changes in scope of the project, cash flow and financial difficulties faced by contractors, and delays in decision making and adequate planning. The findings also indicate the major impacts of cost overruns as time overrun, increased project cost due to extension of time, disputes between owner and contractor, bankruptcy and wastage of tax payers' money. Furthermore, the measures for minimising cost overruns in public sector construction projects in Port Harcourt were the use of experienced contractors, proper project planning, the appointment of highly experienced committed design teams, effective strategic planning and proper project scheduling, while the critical success factors for public sector construction projects were the experience of the project manager, the experience of the contractor, the commitment of project team members, proper planning, awarding the bid to the right contractor, effective decision making and clear and realistic project goals. The study concludes by stressing that projects in Port Harcourt must be properly planned with enough details so that team members know where the project is headed. It was thus recommended that cost overruns in public sector construction projects in Port Harcourt could be minimized by careful management, proper planning by contractors, prompt release of funds by the employer and engagement of experienced contractors by the clients.
\end{abstract}

Index Terms- Cost overruns, Public sector, Construction projects, Port Harcourt, Nigeria

\section{INTRODUCTION}

Memon, Rahman, \& Aziz (2012), emphasize that the socio-economic growth of a country depends to a large extent on the construction industry as it provides necessary infrastructure such as roads, hospitals and schools and other enhanced facilities. Also, it contributes significantly to the county's gross domestic product (GDP). Hence, it is crucial that construction projects are completed successfully within time, budget and expected quality constraints (Cantarelli, 2019; Olawale and Sun, 2010). Construction is a contract-centred activity, with transactional contracts or assignments defining and balancing the objectives of various participants. Coordination between organizations or crew is primarily controlled from a central plan that establishes sequence and determines when an activity will start (Olawale and Sun, 2010). According to Ramanathan, Narayanan and Idrus (2012), the construction process can be divided into three important phases, namely, project design, project construction and project completion. Thus, being a complex and schedule-driven industry, Cantarelli (2009), Olawale and Sun (2010) opined that construction is always faced with chronic problems such as low quality and productivity, cost overrun, time overrun, construction waste and others. Of all these, cost overrun is a severe problem because it affects the overall development of the country (Olawale and Sun, 2010).

Cost is one of the primary measures of a project's success. This is true, especially for public projects in developing countries like Nigeria, because public construction projects in these countries are executed with scarce financial resources. Most literature review on construction projects suggest that the common criteria for project success are generally considered to be cost, time and quality (Frimpong, Oluwoye, and Crawford, 2003). A project is deemed successful if it is completed on budget, on 
schedule, conformed to user expectations, met specifications, attained quality of workmanship and minimized construction aggravation (Olawale and Sun, 2010). Generally, a project is considered successful in Nigeria if the project is completed within a stated cost or budget, getting the project into use by a target date, meets the technical specification, and if there is a high level of satisfaction concerning the project outcome among the project participants. Chitkara (2011) reported that cost is the budgeted expenditure, which the client agrees to commit to creating or acquiring the desired construction facility.

Cost overrun is the difference between the actual final cost of a construction project at completion and the contract amount, agreed by the contractor and the owner during the signing of the contract. Cost overrun also called cost increase, cost escalation or budget overrun. Cost overrun is described as the ratio of the change in the original contract amount to the original contract award amount. For the ease of comparison, the cost overrun can be converted into a percentage value. Mathematically it can be expressed as Cost overruns $=($ Final Contract Amount - Original Contract Amount $) /$ Original Contract Amount (Endut, Akintoye. and Kelly, 2005)

In today's construction industry, cost overrun is a very common phenomenon globally. In a study conducted by Omoregie and Radford (2006), it was reported that a minimum average of cost escalation in construction projects in Nigeria is 14\% every year. Cost overruns in construction projects can occur due to various causes, and a number of researchers have investigated the various causes of cost overruns. For instance, Ameh, Soyingbe,and Odusami,(2010) in their study investigating 42 cost overrun cases, found that lack of experience of contractors, cost of material, fluctuation in the prices of material, frequent design changes, economic stability, high interest rates charged by banks on loans and mode of financing, bonds and payments as well as fraudulent practices and kickbacks were dominant factors causing cost overruns in Nigeria. Doloi (2011) found out in his work that factors causing cost overruns in construction projects in Nigeria were increment of materials prices, delay in supply of raw materials and equipment by contractors, fluctuations in the cost of building materials, unsettlement of the local currency in relation to dollar value, project materials monopoly by some suppliers, resources constraint of funds and associated auxiliaries, not being ready, lack of cost planning/monitoring during pre-and post-contract stages, improvements to standard drawings during construction stage, design changes and inaccurate quantity take-off.

The problem of cost overruns is not only prevalent in Nigeria. It is global. For instance, Le-Hoai, Young, \& Jun (2008).found out that poor site management and supervision, poor project management assistance, financial difficulties of owner, financial difficulties of contractor, design changes were most severe and common causes of cost overrun in Vietnamese construction industry. Also, Memon et al. (2010) investigated large projects in Malaysia and found out that cash flow and financial difficulties faced by contractors, contractor's poor site management and supervision, inadequate contractor experience, shortage of site workers, incorrect planning and scheduling by contractors were most severe factors that cause cost overruns, while changes in scope of project and frequent design changes were least affecting factors on construction cost.

To corroborate the above findings, Atkinson (1999) posited that a construction project is considered to be a success when it applies the iron triangle constraints: time, cost, and quality. According to Atkinson, the iron triangle was originally conceived as a framework to enable project managers to evaluate and balance the competing demands of cost, time and quality of their projects. Subsequently, Shenhar and Dvir (2007) stated that it has become the de facto method to define and measure project success, with the general perception amongst project managers that a successful project is based upon these three criteria alone.

A project is therefore a one-off scope of work, of predetermined cost, and designed to bring about a change of a defined quality performance in a given time (Modesto and Tichapondwa, 2019). Olumide mentioned that construction projects vary in size, type and fundamental structural characteristics. Regardless of the differences in scope, all projects require adequate planning (Olumide, 2009). The author further stated that thorough planning prepares stakeholders for the major risks that may be encountered during the course of a project, and enables them to meet project objectives exactly or within acceptable cost and schedule deviations from initial budgets.

A project always starts with a need or demand by the owner for the design and construction of a certain facility to provide certain service or product (Oberlender, 2000). According to Oberlender, the first requirement for any civil engineering construction project is the clear definition of the owner's needs and objectives for the project. The world, however, is full of unpredictable forces and undesirable outcomes (Gould and Joyce, 2013). Gould and Joyce emphasised that creating a large facility takes a long time and usually involves a large capital investment therefore cost overruns, delays, and other problems tend to be proportionally monumental. Furthermore, Gould and Joyce (2013) expressed the view that the process of building is complicated by the large number of components that are provided by suppliers. The nature of the products and the parties involved in building depend on time, site conditions, user needs and economic health. Moreover, a building not delivered on time usually costs more than planned, and a late delivery can have cascading impacts throughout an owner's organisation (Gould and Joyce, 2013). In view of the foregoing, this study sought to investigate the critical causes and effect of cost overruns in public sector construction projects in Port Harcourt, Nigeria. 


\section{LITERATURE REVIEW}

\section{Overview of cost overrun}

Cost overrun occurs when the final cost of the project exceeds the initial estimate or budget. Nevertheless, the estimate or initial budget is constantly changing during the execution of the project. For this reason, it is important to be careful with the budget that is going to be taken into account to calculate the overrun of the project (Avots, 1983). According to Avots (1983), cost overrun can be defined as not having achieved the project objectives within the estimated budget. The authors further mentioned that cost overrun is a major problem faced by the construction industry globally and its solution needs serious attention. Rahman et al (2012) explained cost overrun as a result of one or a combination of several causes which are very important to identify for cost-effective performance. Cost overruns are a major problem in both developed and developing countries (Angelo and Reina, 2002). Therefore, the authors mentioned that the problem of cost overruns is critical and needs to be studied to alleviate this issue in the future. Durdyev et al (2012) stated that in developing countries the trend is more severe where the cost overruns sometimes exceed 100 per cent of the estimated cost of the project. Azhar, Farooqui, \& Ahmed (2008) also emphasized that cost overrun is a very frequent phenomenon and is associated with nearly all projects in the construction industry.

Overruns are caused by poor management of the resources such as man, material and money (Durdyey, Ismail, \& Bakar, 2012). According to Baloyi and Price (2003), cost overruns are also common in different types of projects and locations. In addition, cost overruns have become a norm rather than an exception in the construction industry (Baloi and Price, 2003). Park and Papadopoulou (2012) stated that cost overruns affect all project stakeholders. The authors mentioned that cost overruns bring about less return-on-investment for the client and extra charges for end-users. Furthermore, they mean negative publicity for the design team and a loss of client confidence (Park and Papadopoulou, 2012). Cost overruns have plagued governments for decades, even centuries. In a study for the National Bureau for Economic Research, economists Stanley Engerman and Kenneth Sokoloff compared actual costs to originally estimated costs for a sample of large government projects in the United States dating back to the early $19^{\text {th }}$ century. They found a pattern of large cost overruns, and they concluded the following: the Erie Canal (46\% cost overrun), Panama Canal (106\%), Hoover Dam (12\%), Louisiana Superdome (366\%), and the renovation of Yankee Stadium in the 1970s (317\%).

There are several factors that affect the construction cost and various studies have been conducted to address these factors. Low quality materials cause higher construction costs than expected because of the loss of materials during construction. These result from a lack of standards for materials and management systems. The lack of ability to prevent cost overruns or to control construction costs causes many Thai construction companies to fail (Memon et al, 2010). Construction can be considered as a dynamic industry which is constantly facing uncertainties. These uncertainties and the many stakeholders in these kinds of projects make the management of costs difficult which consequently causes cost overruns (Arcila, 2012).

\section{Cost overruns in construction projects}

Generally, the factors that impact on cost performance of the project and cause cost overruns are present from the estimating stage to the completion stage of the project (Baloi and Price, 2003). Morris (1990) conducted one of the first studies with a narrow focus on cost overruns in large projects. Morris (1990) argued that delays in project implementation and cost overruns have become a regular feature of public sector projects. The author then concluded that about 20 to 25 per cent of cost overruns can be attributed to price increases, and the remaining 70 to 75 per cent has to be explained in terms of real factors, such as delays in implementation. The following factors are the main causes of delays and cost overruns: poor project design and implementation, inadequate funding of projects, bureaucratic indecision, and a lack of coordination between enterprises (Morris, 1990).

Winch (2010) stated that common causes of cost overruns are as follows: a lack of clear links between the project and the organisation's key strategic priorities, including agreed measures of success; a lack of clear senior management and ministerial ownership and leadership; a lack of effective engagement with stakeholders; a lack of skills and proven approach to project management and risk management; evaluation of proposals driven by initial price rather than long-term value for money; a lack of understanding of, and contact with the supply industry at senior levels in the organisation; and a lack of effective project team integration between clients, the supplier team and the supply chain.

Lee (2008) examined cost overruns in Korean social overhead capital projects. Based on 161 completed projects he concluded that the causes of cost overruns can be grouped into several major categories: change of scope, delays during constructions, unreasonable estimation and adjustment of project costs, and no practical use of the earned value management system. Various studies which were conducted in different developing countries (Nigeria, Saudi Arabia, Malaysia and Indonesia) confirmed that 
all of the projects currently undertaken in these countries suffer from significant construction cost overruns (Kaming, Olomolaiye, Holt, \& Frank, 1997). Morris (1990), Kaming et al,(1997) and Mansfield, Ugwu and Doran (1994), listed the following as the critical causes of cost overruns: incomplete design at the time of tender, additional work at owner's request, changes in owner's brief, a lack of cost planning/monitoring during pre-and-post contract stages, site/poor soil conditions, adjustment of prime cost and provisional sums, re-measurement of provisional works, logistics due to site location, and a lack of cost reports during construction stage. The authors also identified other factors which are usually ignored as follows: delays in issuing information to the contractor during construction delays; technical omissions at design stage; contractual claims such as extension of time with cost claims; improvements to standard drawings during construction stage; wrong decisions by the supervising team in dealing with the contractor's queries; delays in costing variations and additional works: omissions and errors in the bills of quantities: ignoring items with abnormal rates during tender evaluation, especially with provisional quantities and some tendering manoeuvres by contractors, such as front-loading of rates.

The most important variables of cost overruns have been identified as unpredictable weather, inflationary material cost, inaccurate materials estimates, complexity of project, the contractor's lack of geographical experience, the contractor's lack of project type experience, and non-familiarity with local regulations (Kaming et al, 1997). Mahamid and Bruland (2011) conducted a study to identify the cost overrun causes in road construction projects in the West Bank in Palestine from the consultants' perspective. Their findings revealed that the top five affecting factors are materials' price fluctuation, insufficient time for estimate, experience in contracts, the size of contracts, and incomplete drawings. Park and Papadoulou (2012) identified the contract being awarded to the lowest bidder, inaccurate site investigation, unforeseen site conditions, an inadequate pre-construction study and inaccurate estimates as the top five important causes of cost overruns in transport infrastructure projects in Asia. Memon et al (2012) identified that the causes of cost overrun involve thirty-five common factors which were selected through the literature. The results from their study indicated that fluctuation in materials price, cash flow and financial difficulties faced by contractors, delay in progress payment by owner, and frequent design changes were most dominant factors causing cost overrun.

\section{Impacts of Cost Overruns on Public Construction Projects}

According to Akinsiku and Akinsulire (2012), construction clients demand the timely completion of projects without delay or additional cost. However, the authors indicated that cost and time overruns and interest accumulation on capital are the most frequent impacts of delay in the construction industry although the impacts of delay are slightly more on time overruns than cost overruns. This could be as a result of the contractors' inability to honour contract deadlines and using shortages of material as an excuse or the consultants' inability to implement proper design and obtaining adequate knowledge about the usage of materials (Akinsiku and Akinsulire, 2012). Akisiku and Akinsulire (2012) further stated that causes of delay can be categorised as financially related e.g. client not being able to meet up with the payment of interim certificates; design related e.g. delays in design and frequent change orders; improper project logistic and planning e.g. shortages of resources, late delivery of materials and organisational deficiency and resources management. Planning and scheduling issues may lead to an extension of time on the project, an accumulation of interest on the capital to finance the project and cost overruns due to inflation and fluctuations. Moreover, Akisiku and Akinsulire (2012) mentioned that other impacts are wastages and under-utilisation of man-power resources due to idle workmen because of the non-availability of material to work due to poor logistic arrangements. Akinsiku and Akinsulire (2012) concluded that inadequate contractor experience, inaccurate cost estimates, poor technical performance and workmanship, and a lack of communication all lead to disputes between parties involved, as well as arbitration and litigation, including the total abandonment of project. Inclement weather, restricted access and buildability issues are factors which lead to the under-utilisation of equipment and plant meant for the project, including a reduction in employment opportunities for construction workmen (Akinsiku and Akinsulire, 2012).

Wakjira (2011) also identified the following impacts of cost overrun: losses of credibility to highway organisation; bad reputation; loss of clients' confidence in consultants; added investment risks or funding risks to professionals; the inability to deliver value to clients discouraging sponsors to invest in the construction industry; less returns on investment for clients; delay in payment, loss of profit to the contractor, abandonment of future projects, drop in construction activities; inability to secure project finance or securing it at higher costs preventing planned increase in road network; damage to professional relations; suspension of work; dispute among parties and a decreased rate of national growth. All these consequences undermine the viability and sustainability of the construction industry (Wakjira, 2011). However, Akinsiku and Akinsulire (2012) have a different view, stating that arbitration or litigation and the total abandonment of projects were no longer seen to be the usual impacts of delay as outlined by past researchers. This could be as a result of the implementation of risk management procedure which enables the parties to the contract to terminate, treat, transfer and tolerate contractual risk; hence the number of disputes and court proceedings on construction contracts have declined significantly (Akinsiku and Akinsulire, 2012).

The effect of cost overrun is well documented in literature on cost overrun. Mbachu and Nkado (2004) using a pilot study This publication is licensed under Creative Commons Attribution CC BY. 
executed using descriptive survey method involving qualitative data gathering through semi-structured interviews conducted with a convenience sample made up of (20) twenty principal partners/directors of consulting and contracting firms with a follow up regional questionnaire surveys of 130 identified respondents from various stakeholder groups concluded that impacts of occurrence of cost overruns in construction projects on key project stakeholders and the construction industry is glaring. They highlighted that impacts of cost overrun on project stakeholders ranges from additional project cost to the client which in turn leads to loss of anticipated revenue to be derived from the project (Mahmid, 2013), inability of project consultants to deliver value for money, contractor's loss of profit. The general effect of these on the construction industry as a whole is potentials of abandonment of project, lower reduction of GDP contribution of the industry and loss of skilled workforce due to poor financial performance of contractors.

Cost overrun has obvious impacts for the key stakeholders in particular, and on the construction industry in general. To the client, cost overrun implies added costs over and above those initially agreed upon at the onset, resulting in less returns on investment. To the end user, the added costs are passed on as higher rental/lease/ costs or prices. To the professionals, cost overrun implies inability to deliver value for money and could well tarnish their reputations and result in loss of confidence reposed in them by clients. To the contractor, it implies loss of profit for non-completion, and defamation that could jeopardize his/her chances of winning further jobs, if it is at his fault. To the industry as a whole, cost overrun could bring about project abandonment and a drop in construction activities, bad reputation, and inability to secure project finance or securing it at higher costs due to added risks, Macho and Nkado (2004).

Although the degree of impacts of cost overrun varies on the stakeholders in the construction industry, all the parties involved are affected by cost overrun. The first victim of cost overrun would be the project owner since he has envisaged his construction project to be realized within an allocated cost. Anything outside these stated frames are cost overrun to the client. Cost overrun does not affect only those parties that are involved directly in the construction of a project, but its effect pass to the construction industry as a whole and consequently to the national economy of the country. Cost overrun for public clients, whose financial resources are scarce, has many impacts and it will be a source of friction between the public client and the consultant. When the cost overrun is due to financial constraints of clients, the construction projects suffer lots of problems which further aggravate the problems of cost overrun. For public projects cost overrun will lead to delay as the public clients do not have enough financial resources which are ready to be pumped to the construction project. If a construction project is delayed for a long period of time it will be subjected to inflationary pressure and interests will be accumulated. One of the common impacts of cost overrun is delay; this in turn affects clients, consultants and contractors. Furthermore, lengthy delays increase cost overrun tremendously.

\section{METHODOLOGY}

This research was carried out in Port Harcourt, the capital of Rivers State in the southern part of Nigeria. The city was chosen because it is the hub of industrial, commercial, administrative activities in the state and a hive of construction activities. It is also the major city in the state and has one of the largest seaport in the Niger Delta region of Nigeria. A descriptive survey design was adopted for the study, while the population of the study comprised 178 construction professionals which include architects, builders, engineers, project managers, and quantity surveyors currently working with registered construction companies in Port Harcourt. The sample size was calculated using Taro Yamane's formula as shown in equation 1.

$\mathrm{n}=\frac{N}{1+(e)^{2}}$

when $\mathrm{n}=$ sample size

$\mathrm{N}=$ population

$\mathrm{e}^{2}=$ Margin of error (assumed 5\%)

$1=$ unity or constant

Therefore $=\frac{178}{1+178(0.05)^{2}}=123$

Being a survey research, data was collected through structured questionnaires administered to the respondents. Relevant items in the questionnaire was assessed based on a five-point Likert scale and Mean item scores (MIS) was used for ranking. The indices were then used to determine the rank of each item. These rankings made it possible to cross-compare the relative importance of the items as perceived by the respondents.

The mean item score (MIS) was calculated from the total of all weighed responses and then relating it to the total responses on a particular aspect. The index of MIS of a particular factor is the sum of the respondents' actual scores (on the five-point scale) given by all the respondents as a proportion of the sum of all maximum possible scores on the five-point scale that all the 
respondents could give to the criterion. A weight was assigned to each response. The indices were then used to determine the rank of each item. The mean item score (MIS) is ranked in descending order (from highest to lowest) and is derived from the following formula:

MIS $=\underline{1 n_{1}+2 n_{2}} \underline{+3 n_{3}} \underline{+4 n_{4}} \underline{n}_{5}+5 n_{5}$

Where: $5 \ldots 1$ are the weightings on the Likert Scale

$\mathrm{n}_{1}=$ number of respondents for 'strongly_disagree'

$\mathrm{n}_{2}=$ number of respondents for 'disagree'

$\mathrm{n}_{3}=$ number of respondents for 'neutral'

$\mathrm{n}_{4}=$ number of respondents for 'agree'

$\mathrm{n}_{5}=$ number of respondents for 'strongly agree'

$\mathrm{N}=$ Total number of respondents

Following computations, the criteria were then ranked in descending order of their severity, i.e from the highest to the lowest.

\section{RESULTS AND DISCUSSION}

Table 1. Questionnaire administration and response rate

\begin{tabular}{lll}
\hline Questionnaire & Frequency & Percentage ( \%) \\
\hline Total no of copies of Questionnaire administered & 123 & 0.00 \\
No of copies received & 98 & 79.70 \\
No not received & 25 & 20.30 \\
Total & & $100 \%$ \\
\hline
\end{tabular}

Source: Research's field survey (2020)

Table 1 shows that out of the 123 copies of questionnaires distributed based on the sample size earlier obtained for the study, 98 representing $79.7 \%$ of the total respondents were completed and returned while 25 representing $20.3 \%$ were not returned nor completed. The researcher proceeded with the analysis of the data as $79.7 \%$ response rate is regarded as very satisfactory for this study. According to Babbie and Mouton (2001), some rules of thumb about the return/response rate is that a response rate of $50 \%$ is adequate for analysis and reporting, $60 \%$ is good while $70 \%$ is very good.

Table 2. Respondents' Gender

\begin{tabular}{lll}
\hline Gender & Number of Responses & Percentage (\%) \\
\hline Male & & 72.45 \\
Female & 71 & 27.55 \\
Total & 27 & $\mathbf{1 0 0 \%}$ \\
\hline
\end{tabular}

Source: Research's field survey (2020)

The sex of the respondents as presented in Table 2 indicates that 71 respondents are male, representing $72.45 \%$ of the total respondents and 27 respondents; representing $27.55 \%$ of the total respondents are female. The indication of this is that male respondents showed more interest in this study than their female counterparts.

Table 3. Respondents' Characteristics

\begin{tabular}{llll}
\hline Item & Variables & No of Responses & Percentages \\
\hline Experience & (a) $0-5$ years & 24 & 24.50 \\
& (b) 6-10 years & 28 & 28.6 \\
& (c) $11-15$ years & 21 & 21.4 \\
& (d) $16-20$ years & 15 & 15.30
\end{tabular}




\begin{tabular}{llll} 
& (e) 20 years and above & 10 & 10.20 \\
Total & & $\mathbf{9 8}$ & $\mathbf{1 0 0 \%}$ \\
\hline Field/discipline & (a) Architecture & 18 & 18.37 \\
& (b) Building & 12 & 12.24 \\
& (c) Civil Engineering & 20 & 20.41 \\
& (d) Electrical Engineering & 12 & 12.24 \\
& (e) Mechanical Engineering & 10 & 10.2 \\
& (f) Quantity Surveying & 14 & 14.30 \\
Total & (g) Land Surveying & 7 & 7.14 \\
\hline Academic Qualification & (h) Estate Management & 5 & 5.10 \\
& & $\mathbf{9 8}$ & $\mathbf{1 0 0 \%}$ \\
& (a) Ph.D. & 6 & 6.12 \\
Total & (b) M.Sc & 29 & 29.6 \\
& (c) B.Sc/B Eng & 51 & 52.04 \\
Professional Affiliation & (d) HND & 6 & 6.12 \\
& (e) Others & 6 & 6.12 \\
& & $\mathbf{9 8}$ & $\mathbf{1 0 0 \%}$ \\
& & & \\
\hline & (a) MNIA & 15 & 8.2 \\
(b) MNIOB & 8 & 35.71 \\
& (c) MNSE & 35 & 12.2 \\
& (d) MNIQS & 12 & 6.1 \\
& (e) MNIS & 6 & 4.08 \\
& (f) NIESV/ESVARBON & 4 & 18.4 \\
& (g) OTHERS & 18 & - \\
& & & $\mathbf{1 0 0 \%}$ \\
\hline
\end{tabular}

Source: Research's field survey (2020)

On respondents' experience, Table 3 reveals that 28 respondents representing $28.60 \%$ have worked between 6 to 10 years, 24 of them representing $24.50 \%$ have worked up to 5 years, 21 respondents representing $21.4 \%$ have worked between 11 and 15 years and 15 respondents have also worked between 16 to 20 years, while the remaining 10 respondents which represent $10.20 \%$ have worked up to 20 years and above. The trend therefore, shows that the respondents are experienced and as such can provide informed opinion about the state of contract auditing.

Table 3 also indicates that respondents representing 20.41\% are Civil Engineers, some of them are Architects which represents 18.37\%, and Electrical Engineers 12.24\%, Mechanical Engineers 10.20\%, Builders 12.24\%. Others are Quantity Surveyors who are 14(14.30\%), followed by land surveyors $7.14 \%$ and Estate surveyors are $5.10 \%$ of respondents. This shows that respondents are made up of professionals that can effectively handle contract auditing. In terms of their academic qualification, the table indicates that majority of the 51 respondents representing $52.04 \%$ have first degrees, followed by $29.60 \%$ who have M.Sc. $6.12 \%$ respondents obtained Ph.D., 6 respondents which represents $6.12 \%$ obtained HND and the remaining $6.12 \%$ represent other qualifications. This highlights that the respondents are educated enough to handle construction projects.

Furthermore, regarding the professional affiliations of the respondents; $15(15.31 \%)$ are Architects, they are affiliated with their professional body (MNIA). 35 (35.71\%) are affiliated with the Engineering professional body (MNSE). 8 (8.2\%) are affiliated with Building (MNIOB). $12(12.2 \%)$ are affiliated with Quantity surveyors (MNIQS), equally, 6 respondents representing (6.1\%) are affiliated with Land surveyors (MNIS), 4 respondents representing (4.08\%) are affiliated with Estate profession (NIESV/ESVARBON) and others (18.4\%) representing unidentified affiliation.

Table 4. Ranking of factors causing cost overruns in public sector construction projects in Port Harcourt.

\begin{tabular}{lllll}
\hline S/N & CAUSES OF COST OVERUN & QX & MIS & RANK \\
\hline $\mathbf{1}$ & Variation orders & 0.732 & 4.29 & 1 \\
$\mathbf{2}$ & Change in the scope of the project & 0.673 & 4.24 & 2 \\
$\mathbf{3}$ & Cash flow and financial difficulties faced by contractors & 1.000 & 4.24 & 2 \\
$\mathbf{4}$ & Delays in decision making & 0.881 & 4.18 & 3 \\
$\mathbf{5}$ & Inadequate planning & 0.946 & 4.12 & 4 \\
\hline
\end{tabular}




\begin{tabular}{|c|c|c|c|c|}
\hline 6 & Frequent design changes & 1.069 & 4.03 & 5 \\
\hline 7 & Lack of coordination between parties & 0.963 & 4.02 & 6 \\
\hline 8 & Policy in accepting lowest tender & 1.061 & 4.00 & 7 \\
\hline 9 & Inaccurate time and cost estimate & 0.991 & 3.98 & 8 \\
\hline 10 & Errors and omission in design & 1.040 & 3.96 & 9 \\
\hline 11 & Inaccurate quantity take-off & 1.028 & 3.95 & 10 \\
\hline 12 & Contractors project inexperience & 1.007 & 3.95 & 10 \\
\hline 13 & Extension of time claims & 1.039 & 3.92 & 11 \\
\hline 14 & Change in material specification and type & 1.005 & 3.89 & 12 \\
\hline 15 & Poor contract management & 0.941 & 3.87 & 13 \\
\hline 16 & Delay in progress payment by the owner & 1.125 & 3.85 & 14 \\
\hline 17 & Poor project management & 0.979 & 3.83 & 15 \\
\hline 18 & Fluctuation in material prices & 0.899 & 3.83 & 15 \\
\hline 19 & Poor workmanship & 1.013 & 3.80 & 16 \\
\hline 20 & Lack of communication between parties & 0.972 & 3.79 & 17 \\
\hline 21 & mistake and discrepancies in contract document & 0.973 & 3.75 & 18 \\
\hline 22 & Late delivery of materials & 1.060 & 3.72 & 19 \\
\hline 23 & Incomplete design at the time of tender & 1.181 & 3.72 & 19 \\
\hline 24 & Incomplete sub-contractor & 1.047 & 3.71 & 20 \\
\hline 25 & Mistake during construction & 1.044 & 3.70 & 21 \\
\hline 26 & Slow information flow between parties & 1.009 & 3.70 & 21 \\
\hline 27 & Unforeseen ground conditions & 1.033 & 3.69 & 22 \\
\hline 28 & Delay in payment of supplier/sub-contractor & 1.127 & 3.68 & 23 \\
\hline
\end{tabular}

Source: Research's field survey (2020)

Table 4 represents the factors that cause cost overruns in public sector construction project in Portharcourt as ranked by respondents. The respondents ranked variation orders first ( $\mathrm{MIS}=4.29 ; \mathrm{SD}=0.752 ; \mathrm{R}=1$ ), followed by change in scope of the project (MIS=4.24; $\mathrm{SD}=0.673 ; \mathrm{R}=2$ ) and cash flow and financial difficulties faced by contractors (MIS=4.24; $\mathrm{SD}=1.000 ; \mathrm{R}=2$ ), delays in decision making $(\mathrm{MIS}=4.18 ; \mathrm{SD}=0.881 ; \mathrm{R}=3)$, inadequate planning $(\mathrm{MIS}=4.12 ; \mathrm{SD}=0.946 ; \mathrm{R}=4)$, frequent design changes $(\mathrm{MIS}=4.03 ; \mathrm{SD}=$ $1.069 ; \mathrm{R}=5$ ), lack of coordination between parties (MIS $=4.02 ; \mathrm{SD}=0.963 ; \mathrm{R}=6$ ), policy in accepting lowest tender (MIS $=4.00 ; \mathrm{SD}$ $=1.061 ; \mathrm{R}=7$ ), inaccurate time and cost estimates (MIS = 3.98; $\mathrm{SD}=0.991 ; \mathrm{R}=8$ ), errors and omissions in design $(\mathrm{MIS}=3.96 ; \mathrm{SD}=$ 1.040; $\mathrm{R}=9$ ), inaccurate quantity take-off ( $\mathrm{MIS}=3.95 ; \mathrm{SD}=1.028 ; \mathrm{R}=10)$, contractors' project inexperience (MIS $=3.95 ; \mathrm{SD}=1.007$; $\mathrm{R}=10$ ), extension of time claims ( $\mathrm{MIS}=3.92 ; \mathrm{SD}=1.039 ; \mathrm{R}=11$ ), change in material specification and type (MIS = 3.89; $\mathrm{SD}=1.005$; $\mathrm{R}=12$ ), poor contract management (MIS $=3.87 ; \mathrm{SD}=0.941 ; \mathrm{R}=13$ ), delay in progress payment by the owner $(\mathrm{MIS}=3.85 ; \mathrm{SD}=$ $1.125 ; \mathrm{R}=14$ ), poor project management ( $\mathrm{MIS}=3.83 ; \mathrm{SD}=0.979 ; \mathrm{R}=15$ ), fluctuations in material prices ( $\mathrm{MIS}=3.32 ; \mathrm{SD}=0.899 ; \mathrm{R}$ $=15$ ), poor workmanship (MIS = 3.80; $\mathrm{SD}=1.013 ; \mathrm{R}=16$ ), lack of communication between parties $(\mathrm{MIS}=3.79 ; \mathrm{SD}=0.972 ; \mathrm{R}=17$ ), mistakes and discrepancies in contract document (MIS $=3.75 ; \mathrm{SD}=0.973 ; \mathrm{R}=18$ ), late delivery of materials ( $\mathrm{MIS}=3.72 ; \mathrm{SD}=1.060$; $\mathrm{R}=19$ ), incomplete design at the time of tender (MIS = 3.72; $\mathrm{SD}=1.181 ; \mathrm{R}=19$ ), incompetent sub-contractors ( $\mathrm{MIS}=3.71 ; \mathrm{SD}=$ 1.047; $\mathrm{R}=20$ ), mistakes during construction ( $\mathrm{MIS}=3.70 ; \mathrm{SD}=1.044 ; \mathrm{R}=21$ ), slow information flow between parties (MIS = 3.70; $\mathrm{SD}$ $=1.009 ; \mathrm{R}=21$ ), unforeseen ground conditions ( $\mathrm{MIS}=3.69 ; \mathrm{SD}=1.033 ; \mathrm{R}=22$ ), delay in payment to supplier/sub-contractor (MIS = $3.68 ; \mathrm{SD}=1.127 ; \mathrm{R}=23$ ).

Table 5. Ranking of effect of cost overruns in public sector construction projects in Port Harcourt.

\begin{tabular}{lllll}
\hline S/N & IMPACTS OF COST OVERUN & QX & MIS & RANK \\
\hline $\mathbf{1}$ & Time overrun & 0.734 & 4.52 & 1 \\
$\mathbf{2}$ & Increased project cost due to extension of time & 0.649 & 4.50 & 2 \\
$\mathbf{3}$ & Dispute between owner and contractor & 0.913 & 4.30 & 3 \\
$\mathbf{4}$ & Bankruptcy & 1.147 & 3.98 & 4 \\
$\mathbf{5}$ & Wastage of tax payer's money & 1.145 & 3.92 & 5 \\
$\mathbf{6}$ & Company/ firms liability to insolvency & 0.943 & 3.87 & 6 \\
$\mathbf{7}$ & Reduce profit to contractor & 1.013 & 3.80 & 7 \\
$\mathbf{8}$ & Arbitration & 1.052 & 3.65 & 8 \\
$\mathbf{9}$ & Total project abandonment & 1.192 & 3.59 & 9 \\
$\mathbf{1 0}$ & Idling resources & 1.004 & 3.55 & 10 \\
$\mathbf{1 1}$ & Delaying in getting profit by the clients & 1.047 & 3.49 & 11 \\
$\mathbf{1 2}$ & Creating stress for contractors & 1.126 & 3.45 & 12 \\
\hline
\end{tabular}

This publication is licensed under Creative Commons Attribution CC BY. 


\begin{tabular}{llrrr}
\hline $\mathbf{1 3}$ & Loss of confidence from the public & 1.126 & 3.45 & 12 \\
$\mathbf{1 4}$ & Delaying by clients to return loans & 1.094 & 3.44 & 13 \\
$\mathbf{1 5}$ & Demolition and reconstruction & 1.196 & 3.27 & 14 \\
$\mathbf{1 6}$ & Litigation & 1.175 & 2.97 & 15 \\
\hline
\end{tabular}

Source: Research's field survey (2020)

Table 5 represents the effect of cost overruns in public sector construction project in Portharcourt as ranked by respondents. The respondents ranked time overrun first (MIS=4.52; $\mathrm{SD}=0.734 ; \mathrm{R}=1$ ), followed by Increased project time due to extension of time (MIS = 4.50; $\mathrm{SD}=0.649 ; \mathrm{R}=2$ ), disputes between owner and contractor (MIS = 4.30; $\mathrm{SD}=0.913 ; \mathrm{R}=3$ ), bankruptcy $(\mathrm{MIS}=3.98 ; \mathrm{SD}=$ $1.147 ; \mathrm{R}=4$ ), wastage of taxpayers' money ( $\mathrm{MIS}=3.92 ; \mathrm{SD}=1.145 ; \mathrm{R}=5$ ), company/firms liability to insolvency (MIS $=3.87 ; \mathrm{SD}=$ $1.023 ; \mathrm{R}=6$ ), reduced profit to contractor (MIS $=3.80 ; \mathrm{SD}=1.013 ; \mathrm{R}=7$ ), arbitration ( $\mathrm{MIS}=3.65 ; \mathrm{SD}=1.052 ; \mathrm{R}=8$ ), total project abandonment ( $\mathrm{MIS}=3.59 ; \mathrm{SD}=1.192 ; \mathrm{R}=9$ ), idling resources $(\mathrm{MIS}=3.55 ; \mathrm{SD}=1.004 ; \mathrm{R}=10$ ), delaying in getting profit by the clients (MIS = 3.49; $\mathrm{SD}=1.047 ; \mathrm{R}=11$ ), creating stress for contractors ( $\mathrm{MIS}=3.453 ; \mathrm{SD}=1.126 ; \mathrm{R}=12$ ), loss of confidence from the public (MIS = 3.45; $\mathrm{SD}=1.126 ; \mathrm{R}=12$ ), delaying by the clients to return loans ( $\mathrm{MIS}=3.44 ; \mathrm{SD}=1.094 ; \mathrm{R}=13$ ) while demolition and reconstruction were ranked second last $(\mathrm{MIS}=3.27 ; \mathrm{SD}=1.196 ; \mathrm{R}=14)$ and litigation was raked last $(\mathrm{MIS}=2.97 ; \mathrm{SD}=1.175 ; \mathrm{R}=$ $15)$.

Table 6. Measures for minimizing cost overruns in public sector construction projects in Port Harcourt

\begin{tabular}{lllll}
\hline S/N & Measures for minimizing cost overrun in public sector construction & QX & MIS & RANK \\
& project & 0.846 & 4.741 & 1 \\
\hline $\mathbf{1}$ & Use of experience suppliers & 0.649 & 4.50 & 2 \\
$\mathbf{2}$ & Proper project planning & 0.711 & 4.49 & 3 \\
$\mathbf{3}$ & Appointment of highly experience committed design team & 0.675 & 4.48 & 4 \\
$\mathbf{4}$ & Effective strategic planning & 0.648 & 4.45 & 5 \\
$\mathbf{5}$ & Proper project scheduling & 0.789 & 4.45 & 5 \\
$\mathbf{6}$ & Completed designs at the time of tender & 0.744 & 4.44 & 6 \\
$\mathbf{7}$ & Decreased number of variation orders & 0.656 & 4.41 & 7 \\
$\mathbf{8}$ & Adequate design & 0.642 & 4.40 & 8 \\
$\mathbf{9}$ & Timely supply of material & 0.667 & 4.39 & 9 \\
$\mathbf{1 0}$ & Comprehensive contract administration & 0.725 & 4.38 & 10 \\
$\mathbf{1 1}$ & Appointment of highly experienced technical consultants & 0.649 & 4.37 & 11 \\
$\mathbf{1 2}$ & Good workmanship & 0.728 & 4.34 & 12 \\
$\mathbf{1 3}$ & Use appropriate construction methods & 0.705 & 4.33 & 13 \\
$\mathbf{1 4}$ & Effective site management & 0.833 & 4.32 & 14 \\
$\mathbf{1 5}$ & Improving contract award procedures by giving less weight to prices & and & & \\
& more weight to the capabilities and past performance of contractors & & & \\
$\mathbf{1 6}$ & Proper emphasis on past experience & 0.913 & 4.30 & 15 \\
$\mathbf{1 7}$ & Effective site supervision & 0.715 & 4.28 & 16 \\
$\mathbf{1 8}$ & Frequent progress meetings & 0.902 & 4.30 & 17 \\
$\mathbf{1 9}$ & Use of experience sub-contractors and suppliers & 0.776 & 4.12 & 18 \\
$\mathbf{2 0}$ & Clear information and communication channels & 0.650 & 4.00 & 19 \\
$\mathbf{2 1}$ & Frequent coordination between the parties & 0.699 & 3.89 & 20 \\
$\mathbf{2 2}$ & Use of up-to-date technology & 0.866 & 3.75 & 21 \\
$\mathbf{2 3}$ & Use of experienced contractors & 0.736 & 2.97 & 22 \\
$\mathbf{2 4}$ & Reliable pre-contract estimates & 0.721 & 2.03 & 23 \\
\hline $\mathbf{S 0 u r}$ & Reserch's & & \\
\hline
\end{tabular}

Source: Research's field survey (2020)

Findings from the study indicates measures that can be taken to minimise cost overruns in the public sector with regards to construction projects in Portharcourt as shown in Table 6. The respondents ranked the use of experienced suppliers first (MIS $=4.74 ; \mathrm{SD}=0.846 ; \mathrm{R}=$ 1 ), followed by proper project planning (MIS $=4.50 ; \mathrm{SD}=0.649 ; \mathrm{R}=2$ ), appointment of highly experienced committed design teams (MIS = 4.49; $\mathrm{SD}=0.711 ; \mathrm{R}=3$ ), effective strategic planning ( $\mathrm{MIS}=4.48 ; \mathrm{SD}=0.675 ; \mathrm{R}=4$ ), proper project scheduling (MIS = 4.45; 
$\mathrm{SD}=0.648 ; \mathrm{R}=5$ ) and completed designs at the time of tender (MIS $=4.45 ; \mathrm{SD}=0.789 ; \mathrm{R}=5$ ), decrease number of variation orders $(\mathrm{MIS}=4.44 ; \mathrm{SD}=0.744 ; \mathrm{R}=6)$, adequate designs (MIS $=4.41 ; \mathrm{SD}=0.656 ; \mathrm{R}=7)$, timely supply of materials $(\mathrm{MIS}=4.40 ; \mathrm{SD}=$ $0.642 ; \mathrm{R}=8$ ), comprehensive contract administration ( $\mathrm{MIS}=4.39 ; \mathrm{SD}=0.667 ; \mathrm{R}=9$ ), appointment of highly experienced technical consultants ( $\mathrm{MIS}=4.38 ; \mathrm{SD}=0.725 ; \mathrm{R}=10$ ), good workmanship ( $\mathrm{MIS}=4.37 ; \mathrm{SD}=0.649 ; \mathrm{R}=11$ ), use of appropriate construction methods (MIS $=4.34 ; \mathrm{SD}=0.728 ; \mathrm{R}=12$ ), effective site management (MIS = 4.33; $\mathrm{SD}=0.705 ; \mathrm{R}=13$ ), improving contract award procedures by giving less weight to prices and more weight to the capabilities and past performance of contractors $(\mathrm{MIS}=4.32 ; \mathrm{SD}=$ $0.833 ; \mathrm{R}=14$ ), proper emphasis on past experience (MIS $=4.30 ; \mathrm{SD}=0.913 ; \mathrm{R}=15$ ), effective site supervision $(\mathrm{MIS}=4.28 ; \mathrm{SD}=$ $0.715 ; \mathrm{R}=16$ ), frequent progressive meetings (MIS $=4.30 ; \mathrm{SD}=0.902 ; \mathrm{R}=17$ ), use of experienced sub-contractors and suppliers(MIS $=4.12 ; \mathrm{SD}=0.776 ; \mathrm{R}=18)$, clear information and communication channels ( $\mathrm{MIS}=4.00 ; \mathrm{SD}=0.650 ; \mathrm{R}=19$ ), frequent coordination between the parties (MIS $=3.89$; $\mathrm{SD}=0.699 ; \mathrm{R}=20$ ), use of up-to- date technology ( $\mathrm{MIS}=3.75 ; \mathrm{SD}=0.866$; $\mathrm{R}=21$ ), use of experienced contractors $(\mathrm{MIS}=2.97 ; \mathrm{SD}=0.736 ; \mathrm{R}=22)$, while reliable pre-contract estimates was ranked last $(\mathrm{MIS}=2.03 ; \mathrm{SD}=$ $0.721 ; \mathrm{R}=23)$.

Table 7. Critical success factors for construction projects in Port Harcourt

\begin{tabular}{lllll}
\hline S/N & Critical success factors for construction projects & QX & MIS & RANK \\
\hline $\mathbf{1}$ & Experience of project manager & 0.503 & 4.68 & 1 \\
$\mathbf{2}$ & Experience of contractor & 0.556 & 4.61 & 2 \\
$\mathbf{3}$ & Commitment of project team members & 0.526 & 4.60 & 3 \\
$\mathbf{4}$ & Proper planning & 0.642 & 4.60 & 3 \\
$\mathbf{5}$ & Awarding bid to right contractor & 0.601 & 4.60 & 3 \\
$\mathbf{6}$ & Effective decision making & 0.547 & 4.56 & 4 \\
$\mathbf{7}$ & Clear and realistic goals & 0.564 & 4.56 & 4 \\
$\mathbf{8}$ & Competence of project team members & 0.534 & 4.53 & 5 \\
$\mathbf{9}$ & Adequacy of funding & 0.636 & 4.51 & 6 \\
$\mathbf{1 0}$ & Learning from previous experience & 0.732 & 4.44 & 7 \\
$\mathbf{1 1}$ & Top management experience and support & 0.678 & 4.39 & 8 \\
$\mathbf{1 2}$ & Sufficient resources & 0.607 & 4.36 & 9 \\
$\mathbf{1 3}$ & Good written contract & 0.700 & 4.32 & 10 \\
$\mathbf{1 4}$ & Access to resources & 0.673 & 4.32 & 11 \\
$\mathbf{1 5}$ & Stakeholder satisfaction & 0.833 & 4.19 & 12 \\
$\mathbf{1 6}$ & Stable political environment & 0.907 & 3.92 & 13 \\
$\mathbf{1 7}$ & Client experience & 0.967 & 3.92 & 14 \\
$\mathbf{1 8}$ & Effective communication & 0.607 & 3.03 & 15 \\
$\mathbf{1 9}$ & Project monitoring & 0.580 & 2.82 & 16 \\
\hline
\end{tabular}

Source: Research's field survey (2020)

Table 7 represents the critical success factors for construction projects. The respondents ranked the experience of the project manager first (MIS $=4.68 ; \mathrm{SD}=0.503 ; \mathrm{R}=1$ ), followed by the experience of the contractor $(\mathrm{MIS}=4.61 ; \mathrm{SD}=0.556 ; \mathrm{R}=2$ ), commitment of project team members (MIS $=4.60 ; \mathrm{SD}=0.526 ; \mathrm{R}=3$ ), proper planning (MIS $=4.60 ; \mathrm{SD}=0.642 ; \mathrm{R}=3$ ), awarding the bid to the right contractor(MIS = 4.60; $\mathrm{SD}=0.601 ; \mathrm{R}=3$ ), effective decision making (MIS = 4.56; $\mathrm{SD}=0.547 ; \mathrm{R}=4$ ), clear and realistic goals (MIS = 4.56; $\mathrm{SD}=0.564 ; \mathrm{R}=4)$, competence of project team members ( $\mathrm{MIS}=4.53 ; \mathrm{SD}=0.534 ; \mathrm{R}=5$ ), adequacy of funding (MIS = 4.51; $\mathrm{SD}$ $=0.636 ; \mathrm{R}=6$ ), learning from previous experience (MIS $=4.44 ; \mathrm{SD}=0.732 ; \mathrm{R}=7$ ), top management experience and support (MIS = 4.39; $\mathrm{SD}=0.678 ; \mathrm{R}=8$ ), sufficient resources ( $\mathrm{MIS}=4.36 ; \mathrm{SD}=0.607 ; \mathrm{R}=9$ ), good written contract $(\mathrm{MIS}=4.32 ; \mathrm{SD}=0.700 ; \mathrm{R}=10)$, access to resources (MIS $=4,32 ; \mathrm{SD}=0.673 ; \mathrm{R}=11$ ), stakeholder satisfaction ( $\mathrm{MIS}=4.19 ; \mathrm{SD}=0.833 ; \mathrm{R}=12$ ), stable political environment (MIS = 3.92; $\mathrm{SD}=0.907 ; \mathrm{R}=13$ ), client experience (MIS = 3.92; $\mathrm{SD}=0.967 ; \mathrm{R}=14$ ), while effective communication was ranked second last (MIS $\equiv 3.03 ; \mathrm{SD}=0.607 ; \underline{\mathrm{R}}=15)$ and project monitoring was ranked last $(\mathrm{MIS}=2.82 ; \mathrm{SD}=0.580 ; \mathrm{R}=16)$.

\section{SUMMARY, CONCLUSION AND RECOMMENDATIONS}

The findings from the analysis indicate the following as the critical causes of cost overruns in Port Harcourt, Nigeria: variation orders, changes in scope of the project, cash flow and financial difficulties faced by contractors, delays in decision making, inadequate planning, frequent design changes and lack of coordination between parties. However, the results of the study did not agree with those of the study by Ameh et al (2010), where a lack of experience of contractors, the cost of materials and fluctuations in the prices of materials were revealed as the major causes of cost overruns in construction projects in Nigeria. Furthermore, the results of the current study did not 
agree with the study by Lo, Fung, \& Tung (2006) where the study identified an exceptionally low bid, inadequate resources due to contractor/lack of capital and inexperienced contractors as the major causes of cost overruns.

The research also revealed these factors as the major impacts of cost overruns in public sector construction projects in Port Harcourt: extension of time claims, time overrun and loss of profit to the contractor through damages for non-completion. The following impacts of cost overruns were perceived by the respondents as the most significant: time overrun, additional overhead and potential claims between client and contractor. These results were similar to the findings from the studies by Owolabi et al (2014) and Mbahu and Nkado (2004), where time delay and additional overhead and potential claims between client and contractor were revealed as the major impacts of cost overruns in construction projects. The results of the current study were not in agreement with the study by Ubani, Okorocha, \& Emeribe (2013) where the results showed inconsistency in agreement terms due to changes in political powers and scope creep as the major impacts of cost overruns in construction projects.

In order to prevent cost overruns or minimise their occurrence, the study revealed the following: effective site management, proper project planning, proper project scheduling, effective site supervision, appointment of highly experienced committed design teams, appointment of highly experienced technical consultants, use of experienced contractors, use of appropriate construction methods, clear information and communication channels, frequent coordination between the parties, effective strategic planning, good workmanship, a decreased number of variation orders, completed designs in time of tender, reliable pre-contract estimates and adequate designs. The following were perceived as the most significant mitigation measures by the respondents: the experience of the project manager, the experience of the contractor, the commitment of project team members, proper planning, awarding the bid to the right contractor and effective decision making. The results of this study were similar to the findings revealed by Memon et al (2012), where effective strategic planning, use of experienced sub-contractors and suppliers and proper project planning and scheduling were revealed as the major measures that can be taken to minimise the impact of cost overruns in construction projects. However, the study by Ali and Kamaruzzaman (2010) indicated different results, where proper project costing, financing, proper cost control and competent personnel were revealed as the major measures that can be taken to minimise the impact of cost overruns in construction projects.

To complete a project successfully is key/crucial in the construction industry. The major critical success factors indicated by the respondents are the following: sufficient resources, access to resources, a good written contract, awarding the bid to the right contractor, the commitment of the project team members, the competence of project team members, the experience of the project managers, top management experience and support, and the experience of the contractor. The results for this study were in agreement with the results of a study by Gudiene, Ramelyte, \& Banaitis (2013), where the experience of the project manager, the experience of the contractor, the competence of project team members and clear and realistic goals were determined as the most important success factors for construction projects.

All projects must be properly planned with enough details so that everyone involved knows where the project is going. A good/sound plan provides the following benefits: a valid and realistic timeline, clearly documented project milestones and deliverables, details of resource requirements, accurate cost estimates, and an early warning system. These provide visibility of task slippage and keep the project team focused and aware of progress.

Based on the findings of the research, the following recommendations are proposed:

a) The appointment of contractors should be in accordance with their capabilities and evidence of ability in knowledge and skills required to complete the project.

b) Owners should prepare sufficient funds for the project and pay on time as shown in the contract agreement to the contractor.

c) The personnel performing estimating duties should be provided with the right training and information by stakeholders

d) Enough time should be allocated during tender planning for the proper development of the project programme.

e) Experienced personnel that have handled similar types of complexity in the past should be allocated to the project.

f) A stringent process must be in place for selecting sub-contractors into the supply chain and properly directing the subcontractors to ensure they know what is expected of them in relation to the project.

g) Appropriate funding levels should always be determined at the planning stage of the project so that regular payment should be paid to contractors for work done.

h) Adequate and realistic project duration should be ensured, allowing for potential project delays

i) There needs to be a prompt system of payment to sub-contractors for jobs that have been done and to prevent sub-contractors' financial difficulties.

j) Adequate allowance should be prepared for any emergency case in order to cover increases in material cost and labour cost due to inflation. 


\section{REFERENCES}

[1] Akinsiku, O. E. \& Akinsulire, A., (2012). Stakeholders' Perception of the Causes and Impacts of Construction Delays on Project Delivery. Journal of Construction Engineering and Project Management, 2(4), 25-31.

[2] Ali, A. \& Kamaruzzaman, S., (2010). Cost Performance for Building Construction Projects in Klang Valley. Journal of Building Performance, 1(1), $110-118$.

[3] Ameh, O., Soyingbe, A. \& Odusami, K., (2010). Significant Facotrs Causing Cost Overruns in Telecommunication Projects in Nigeria. Journal of Construction in Developing Countries, 15(2), 49-67.

[4] Arcila, S., (2012). Avoiding Cost Overruns in construction Projects in the UK. M.Sc. Programme and Project Management University of Warwick ed. United Kingdom: Warwick Manufacturing Group.

[5] Atkinson, R., (1999). Project Management: Cost, Time and Quality, Two best guesses and a phenomenon, it's time to accept other success criteria. International Journal of Project Management, 17(6), 337-342.

[6] Avots, I., (1983). Cost-Relevance Analysis for Overrun Control. International Journal of Project Management, 1(3), 142-148.

[7] Azhar, N., Farooqui, R. \& Ahmed, S., (2008). Cost Overrun Factors in Construction Industry in Pakistan. First International Conference in Construction in Developing Countries (ICCIDC-I) 499-508.

[8] Babbie, E. \& Mouton, J. (2001) The Practice of Social Research. South Africa Oxford University Press, Cape Town.

[9] Baloi, D. \& Price, A., (2003). Modelling Global Risk Factors Affecting Construction. Cost Performance, International Journal of Project Management, 21, 261269

[10] Cantarelli, C., (2009). Cost Overruns in Dutch Transportation Infrastructure Projects. Bijdrage aan het Colloquium Vervoersplanologisch Speurwerk (Contribution to the Transport Planning Research Colloquium), 22, 49-56.

[11] Chitkara, K.K. (2011), Construction Project Management - Planning, Scheduling and Controlling, 2nd Edition, Tata McGraw Hills

[12] Doloi, H., (2011). Understanding Stakeholders' Perspective of Cost Estimation in Project Management. International Journal of Project Management, 29(5), 622636.

[13] Durdyey, S., Ismail, S. \& Bakar, N., (2012). Factors Causing Cost Overruns in Construction of Residential Projects: Case Study of Turkey. International Journal of Science and Manageent, 1(1), 3-12.

[14] Endut, I., Shehu, Z., Akintoye, A. \& Jaafar, A., (2009). Cost and Time of Construction Projects in Malaysia. Instabul, $243-252$.

[15] Frimpong, Y. \& Oluwoye, J., (2003). Significant Factors Causing Delay and Cost Overruns in Construction of Groundwater Projects in Ghana. Journal of Construction Research, 1(2), 175-187.

[16] Gould, F., Nancy, E. \& Joyce, N., (2003). Construction Project Management. 2nd ed. New Jersey: Printice Hall.

[17] Gudiene, N., Ramelyte, L. \& Banaitis, A., (2013). An Evaluation of Critical Success Factors for Construction Projects using Expert Judgment. 1st International Vitual Scientific Conference, pp. 384-389.

[18] Kaming, P., Olomolaiye, P., Holt, G. \& Frank, C., (1997). Factors Influencing Construction Time and Cost Overruns on High-rise Projects in Indonesia. Construction Management and Economics, 15(1), 83-94.

[19] Lee, L., (2008). Cost Overrun and Cause in Korean Social Overhead Capital Projects: Roads, Rails, Airports. adn Ports. Journal of Urban Planning and Development, 134, 59-62.

[20] Le-Hoai, L., Young, D. \& Jun, Y., (2008). Delay inVietnam Large Construction Projects: A Comparison with Other selected Countries. KSCE Journal of Civil Engineering, 12(6), 367-377.

[21] Lo, T., Fung, I. \& Tung, K., (2006). Construction delay in Hong Kong civil engineering projects. Journal of Construction Engineering and Management, 132(6), 636-649.

[22] Mahamid, I., (2013). Common Risks Affecting Time Overrun in Road Construction Projects in Palestine: Contractor's Perspective. Australasian Journal of Construction Economics and Building, 13(2), 45-53.

[23] Mansfield, N., Ugwu, O. \& Doran, T., (1994). Causes of Delay and Cost Overruns in Nigerian Construction Projects. International Journal of Project Management, 12(4), 254-260.

[24] Mbachu, J., \& Nkado, R. (2004). Reducing building construction costs; the views of consultants and contractors. Paper presented at the Proceedings of the International Construction Research Conference of the Royal Institution of Chartered Surveyors, Leeds Metropolitan University

[25] Memon, A., Rahman, I. \& Aziz, A., (2012). The Cost Factors of Large Projects' Cost Overrun: A Survey in the Southern part of Peninsular Malaysia. International Journal of Real Estate Studies, 7(2), 1-15.

[26] Morris, P. \& Hough, G., (1987). The Anatomy of Major Projects. A Study of the Reality of Project Management. 1st ed. New York: John Wiley and Sons.

[27] Oberlender, G. D., (2000). Project Management for Engineering and Construction. 2nd ed. United States of America: McGraw -Hill Higher Education.

[28] Olawale, Y. \& Sun, M., (2010). Cost and Time Control of Construction Projecs: Inhibiting factors and Mitigating Measures in Practice. Management and Economics, 28(5), 509-526.

[29] Olumide, A., (2009). Sliding Scale Contingencies for the Highway Construction Project Development Process, s.l.: MSc Thesis for Texas A\&M University.

[30] Omoregie, A. \& Radford, D., (2006) 'Infrastructure Delays and Cost escalations: causes and impacts in Nigeria'. Proceedings of the 6th International Postgraduate Research Conference in the Built and Human Environment, Delft University of Technology, 3-4 April.

[31] Owolabi, J. et al., (2014). Causes and Impacts of Delay on Project Construction Delivery Time. International Journal of Education and Research, 2(4),197-208.

[32] Park, Y. \& Papadopoulou, T., (2012). Causes of Cost Overruns in Trasport Infrastructure Projects in Asia: Their Significance and Relationship with Project Size. Bulit Environment Project and Asset Management, 2(2), 195-216.

[33] Rahman, I. et al., (2012). Time and Cost Performance in Construction Projects in Southern and Central Regions of Peninsular Malaysia. Inrenational Journal of Advances in Applied Sciences, 1(1), 46-51.

[34] Ramanathan, C., Narayanan, S. \& Idrus, A., (2012). Construction Delays Causing Risks On Time and Cost- A Critical Review. Australasian Journal of Construction Economics and Building, 12(1), 37-57.

[35] Shenhar, A. J. , \& Dvir, D. (2007). Reinventing project management: The diamond approach to successful growth and innovation. Boston: Harvard Business School Press.

[36] Ubani, E., Okorocha, K. \& Emeribe, S., (2013). Analysis of Factors Influencing Time and Cost Overrun on Construction Projects in South Eastern Nigeria. International Journal of Management Sciences and Business Research, 73-84.

[37] Wakjira, T., (2011). Risk Factors Leading to Cost Overrun in Ethopian Federal Road Construction Projects and its Consequences, MSc Thesis for University of Ethiopia.

[38] Winch, G., (2010). Managing Construction projects: An Information Prosessing approach. UK: Blackwell Publishing Ltd.

\section{AUTHORS}

This publication is licensed under Creative Commons Attribution CC BY.

http://dx.doi.org/10.29322/IJSRP.11.10.2021.p11835

WwW.ijsrp.org 
First Author - Olupitan, A.L., Managing Partner, A.L Oluptan \& Partners Ltd, Port Harcourt, Rivers State, Nigeria.

Second Author - Ajator,U.O., Professor, Department of Quantity Surveying, Nnamdi Azikiwe University, Awka,, Nigeria

Third Author - Nzeneri, O.P.., Assistant Lecturer, Department of Building, Federal University of Technology, Owerri, Nigeria 
